\title{
14 \\ Imagining Mumeka: Bureaucratic and Kuninjku perspectives
}

\author{
Jon Altman
}

Mumeka is the name of a place; it was once the location of a seasonal camp. Since the late 1960s it has been called an outstation or homeland. The name first appears in the archive in the late 1960s, but the immediate precursor to its establishment was the blazing of a vehicular track from Oenpelli to Maningrida in the Northern Territory in 1963 that crossed the Mann River adjacent to this wet season camp (see Figure 14.1). That place was inhabited by members of a community that speak what we now refer to as the Kuninjku dialect of the pan-dialectical Bining Gunwok language (Evans 2003).

In this chapter, I want to say something about the lives of Kuninjku people over the 50 years since 1963 through the locational lens of Mumeka and their engagements with the Australian state and capitalism, including during a policy period termed self-determination. I then want to say something about current Kuninjku circumstances and the indeterminacy of their future, even as the future of Mumeka, the place, seems reasonably assured.

$1 \quad$ I would like to thank John Mawurndjul and the Kuninjku community for productive collaborations over many years; Melinda Hinkson, Chris Haynes and Dan Gillespie for helpful comments on an earlier draft; Ben Heaslip when at the National Archives of Australia; and anonymous referees for their constructive comments. 


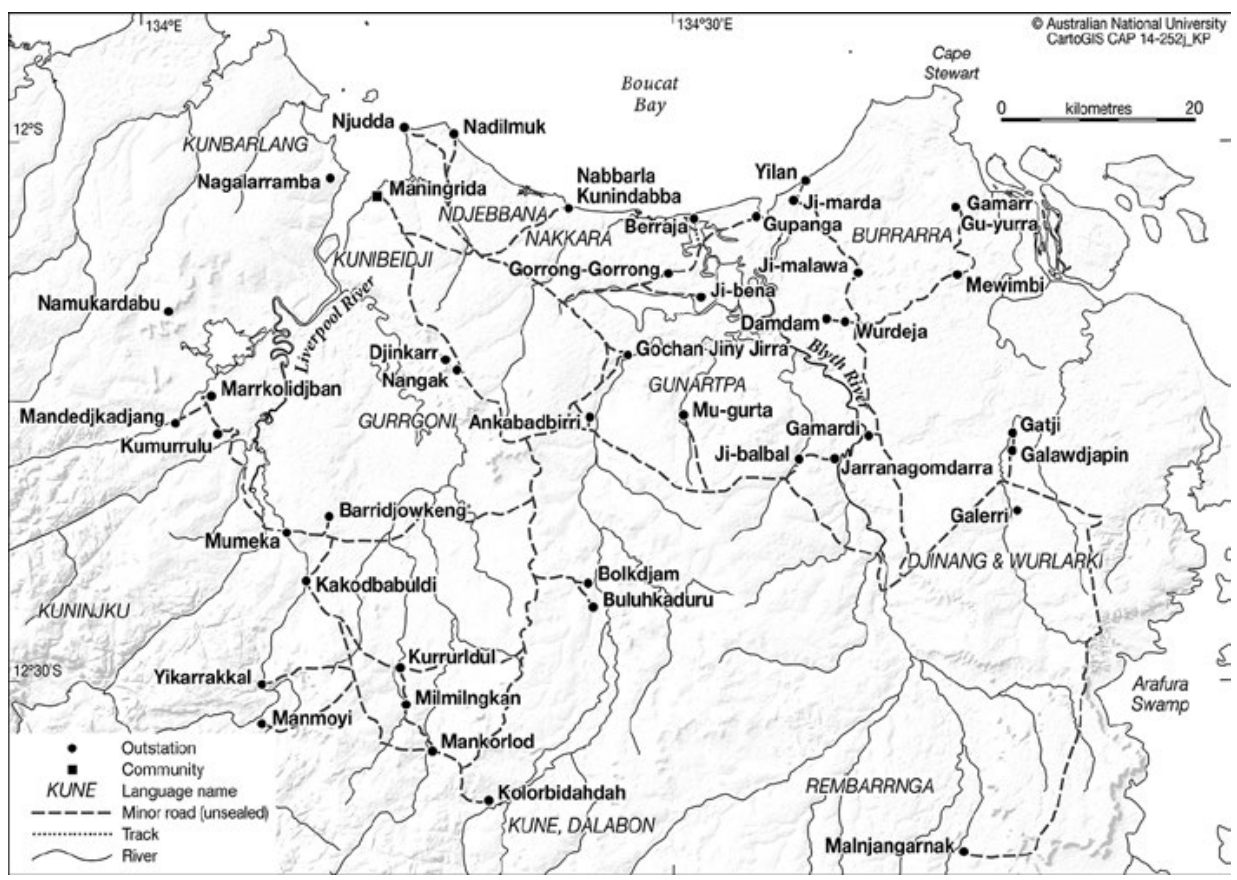

Map 14.1 Mumeka and outstations in the Maningrida region.

Source: Karina Pelling, CartoGIS, ANU College of Asia and the Pacific

\section{Opening vignette}

In 1979 and 1980, I lived with John Mawurndjul at Mumeka. Balang, as he is generally referred to using his subsection name, was a young aspiring artist, hunter, ceremony and family man who decided in the 1980s to focus much energy on painting. By the 1990s, he had become Australia's best-known bark painter. In 2003, he won the Clemenger Prize; in 2004, he was the lead artist at the major retrospective Crossing Country at the Art Gallery of New South Wales in Sydney. In 2005 and 2006, he had a major retrospective, Rarrk John Mawurndjul, at the Museum Tinguely, Basel, and the Sprengel Museum, Hannover; he had books published about him and his arts practice. In 2006, he was heavily involved as the only Australian artist working on site at the Musée du Quai Branly commission, and in 2009 he received the Melbourne Art Foundation Artist of the Year Award - the first Indigenous artist to do so. 


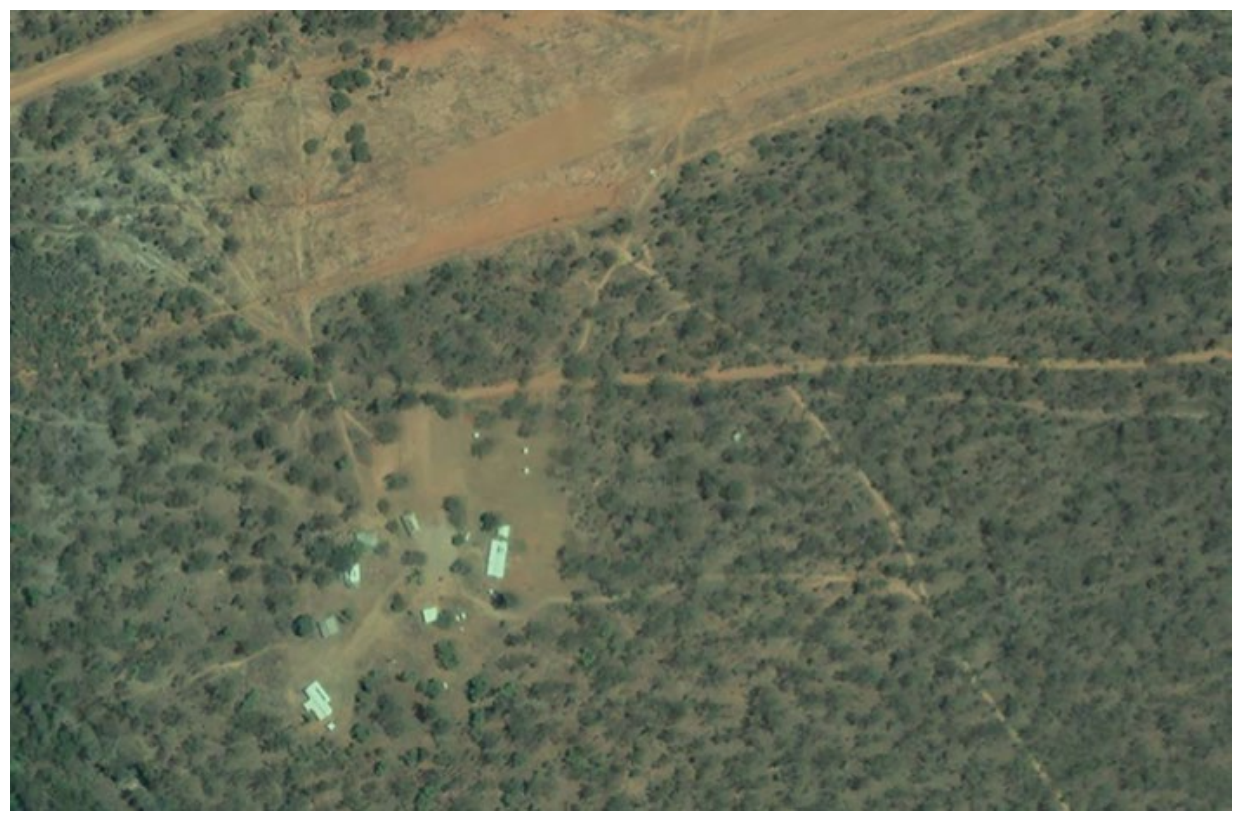

Figure 14.1 An aerial view of Mumeka outstation.

Source: Google Earth

These were happy times; Balang was at his peak, living entirely and very comfortably on his arts earnings. In 2010, he was awarded a Member in the General Division of the Order of Australia '[f]or service to the preservation of Indigenous culture as the foremost exponent of the Rarrk visual art style' (Eccles 2010). ${ }^{2}$ All this is thoroughly documented in the arts literature (see Kaufmann 2005; Volkenandt and Kaufmann 2009).

What is not yet well documented is that after 2009 his career nosedived as his relationships with a string of short-term arts advisers soured; as his arts organisation, Maningrida Arts and Culture, and its parent, Bawinanga Aboriginal Corporation, got into financial difficulties; and how with the Global Financial Crisis (GFC), the demand for Maningrida fine art declined rapidly. That rapid decline for both Balanga and Bawinanga has been exacerbated by changed policy circumstances that have seen a shift from a local form of self-determination and community control to imposed mainstreaming and normalisation and a less-effective mediated relationship between Kuninjku people and the state.

2 See also: www.gg.gov.au/sites/default/files/files/honours/qb/qb2010/Media\%20Notes\%20AM\%20\%28MZ\%29\%20\%28final\%29.pdf (accessed 30 April 2014). 
In 2010, I saw Balang in hospital in Darwin for the first time ever, unwell and psychologically distressed by his rapidly declining arts career. In 2011, he told me of his deep dissatisfaction with the new arts adviser, who was subsequently dismissed. By 2012, he was living in a 'side camp' in the township of Maningrida on Newstart, a social security benefit for the unemployed, dispirited. He had no vehicle to return to his outstation and art studio at Milmilngkan from where he had decentralised from Mumeka in the early 1990s; three years earlier in 2009, he had three four-wheel-drive vehicles in excellent working order: a hunting truck, a family truck and an arts truck.

In September 2013, he told me he had given up painting; there is a large stock of his art at Maningrida Arts and Culture. I watched him, aged over 60, walking to the Ye Ya workshop in the Maningrida industrial precinct looking for a 'real job' as a tyre repairer, as required by the new Remote Jobs and Community Program if one is not to be breached and left destitute with no Newstart and no cash.

I cannot pretend that our relationship is not sadly strained. Balang imagines that I have the power to assist in the repair of his career and to restore the fortunes of Maningrida Arts and Culture and Bawinanga Aboriginal Corporation, institutions that I have worked with closely over many years. I in turn feel deeply frustrated and angry at my inability to make a difference and lament my powerlessness to facilitate a more secure livelihood for his 'retirement'. There is a degree of cross-cultural tension about who is responsible for whom and for what. $^{3}$

This vignette captures metaphorically much of what I want to cover here: the history of the repopulation of Kuninjku outstations in the south-west of the Maningrida hinterland underwritten and then sustained by state transfers and a successful engagement with the global arts market mediated by a local organisation and managed by highly qualified, well-meaning and committed non-Indigenous outsiders; the pursuit of a particular form of highly mobile lifestyle by Kuninjku loosely connected to mainstream services institutions like education and health in Maningrida; and the risks that this way of life entails. I end by pondering what avenues might exist to restore the fortunes of Balang in particular and Kuninjku people more generally if their main avenue for engagement with capitalism continues to decline.

\footnotetext{
3 This tension has been greatly ameliorated by our ongoing friendship and collaborations, most recently at the successful exhibition Rarrk Masters at Annandale Galleries in Sydney, which I opened in April 2015 with Balang in attendance. Balang received significant second payments for barks and hollow log coffins painted before he retired in 2013. He bought a second-hand four-wheel-drive vehicle with this payment and, now aged 63 , is considering rejuvenating his arts practice.
} 


\section{The Gunwinggu problem}

Archival records document what we call today Kuninjku-speaking people living in the upper Tomkinson/Mann/Liverpool rivers region in 1939, 1946, 1949, 1955 and 1963 (Altman 1987: 18-20). Maningrida was established as a government settlement in 1957 and the last of the Kuninjku were coaxed there after a bush track was blazed in 1963 that connected them to Maningrida and Oenpelli, where some had previously lived and worked for short periods. The key catalyst for in-migration was the thoughtful establishment of a leprosarium at Kurrindin near Maningrida, which meant that those afflicted by the disease did not need to be evacuated to East Arm near Darwin, where some Kuninjku had gone, but not returned. Mawurndjul was one among several Kuninjku afflicted with early stages of leprosy —in his case, evident in his hands (Kettle 1967: 206).

The Kuninjku adapted badly to settlement life and its project to sedentarise, civilise and assimilate them. There is archival documentation of what became known as 'the Gunwinggu problem' ${ }^{4}$ One insightful commentary is provided in a 1969 report on Maningrida by project officer E. C. (Ted) Evans in a National Archives of Australia file, 'Social and cultural change-Maningrida'. ${ }^{5}$

Referring specifically to the Gunwinggu, Evans (1969: 27-8) notes:

The alleged non-school attendance of the children of the Gunwinggu tribe was one of the matters I was specifically asked to investigate at Maningrida. I am afraid that my findings are, so far, inconclusive in respect of this phenomena and that I will need to do further investigation before attempting any valid conclusions. However, some very interesting and significant situations were revealed and which justify detailing at this stage.

The Gunwinggu at Maningrida have always given the impression that they are in the community not of it [emphasis in original]. They had their origins in the upper Liverpool River and it is important to note that they have always established their camp on the extreme limits of the Settlement on the shores of the river and in the direction of their tribal country ... I have not been able to establish conclusively that this arrangement has its origins solely with the Gunwinggu or has been partly imposed on them by other groups. However, whatever the cause, this apartness plays some part in the attitude of the Gunwinggu children to schooling.

4 When using historical material, I replicate text and spellings of the time - in particular, the words Mumeka and Kuninjku/Kunwinjku, actually two different dialects of Bining Kunwok, are spelt in a variety of ways, as are a number of placenames.

5 NAA 1973/5087, National Archives of Australia [hereinafter NAA], Darwin. When quoting directly from archival material, I refer to the date of the document (not the date of the file) and to the folio numbers in the file. 
I have deliberately used the expression 'the attitude of the Gunwinggu children' because one fact that I was able to establish quite definitely is that the degree of non-attendance at school by these children is as much, if not more, as a result of their attitude as that of their parents. The quite extraordinary lengths to which some of these children have gone to in their efforts to avoid apprehension for schooling is ample evidence of their determination in this regard.

A persistent theory found among staff members to explain this state of affairs is that children of other tribes 'rubbish' the Gunwinggu children in the school situation. There would appear to be some grounds for this view, as adult members of other tribes have been heard to refer to the Gunwinggus as 'myalls' and 'like animals because they eat bush tucker'. This strange disparagement by sophisticated and semi-sophisticated Aborigines of those who continue to exploit the economy of the traditional life is quite common.

... There is also a strong cohesiveness among this group suggesting that they derive strength and confidence only from within the tribe. I was informed by the Superintendent that on the occasions the Gunwinggu attend the picture shows they arrive in a compact body and remain together throughout the performance. On returning the dancers and their audience to their camp following the abovementioned dancing trials [for Expo '70] I noticed a loud continuous chant emanated from the back of the truck to the effect 'Gunwinggu the best'.

And later:

There is a strong move among the Gunwinggu to move back to the upper reaches of the Liverpool and settle at a place called Mormaka. To facilitate this ... they have purchased and driven to Maningrida a Fordson tractor and a diesel Landrover. The status of the Gunwinggu on their acquiring these vehicles rose astronomically within the Maningrida community ... their plans are by no means as well structured or crystallized as those of the Jinang, nor are they seeking any assistance from the Government ... Again I would adopt the attitude of 'let them have a go' provided adequate provision can be made to meet their emergency health requirements.

Reverting to the education problem, I consider that here we have an opportunity to experiment with a compromise form of schooling. We should do nothing to impede the acquiring of traditional hunting and tracking skills by children where the desire for such skills is still manifest. But if education in these skills could be harmoniously married to more formal education, then the end result may be an even more complete being with a valuable contribution to make to both cultures. My mixing with the Gunwinggu children satisfied me that, despite their broken or lack of education, they have nevertheless acquired good competence in English and in number, which suggests that they are ready and anxious to learn, but that other as yet undefined factors inhibit their going about this in the accepted and established manner. (Evans 1969: 26-7) 
Somewhat presciently and very progressively, Evans suggested that if Kuninjku moved to Mumeka, a young, motivated, male teacher could be placed with them and what we might term today a 'two-way curriculum' could be delivered.

The response from the director of Welfare Services, Harry Giese, was predictably swift and equivocal. In particular, he noted:

Whilst the proposal to establish an outstation for Gunwinggu at the upper reaches of the Liverpool and the suggestion relating to the development of a special curriculum for the children of this group offer some provocative views, I think we need to look very carefully at this proposal if it meant that this group developed a strong feeling against Maningrida as the servicing point for the various communities which would be established in this area ...

I would like to visit Maningrida early in the new year to have discussions ... so that we can point out some of the problems in carrying health and education services to these communities and the limitations which these areas may well place on them in the development of economic projects of various kinds. In saying this, however, I would not like it to be thought that I do not support the proposal. ${ }^{6}$

This exchange is noteworthy on three counts.

First, while 1969 preceded the policy era termed 'self-determination' (from 1972), one does not get the impression that the Gunwinggu were asking permission to move to Mumeka; indeed Evans makes it clear that they are not seeking assistance from government.

Second, Giese's response was interestingly uncertain, suggesting that he was unsure about how to respond to the Gunwinggu initiative. This uncertainty gave his subordinate, John Hunter, scope to act on his own judgment.

Third, there is no attempt to acknowledge that the Gunwinggu were experiencing what we might term today 'structural violence' (Farmer 2005) living in Maningrida; they lived a marginal existence on the edge of the settlement, they experienced discrimination and their physical and psychological health status, as well as access to food, was low.

6 Harry Giese, Correspondence in response to report of Mr Evans dated 25 November 1969, in 'Social and Cultural Change-Maningrida', NAA 1973/5087, folios 38-42, NAA, pp. 40-1. 


\section{The Kuninjku (Gunwinggu) solution}

The Kuninjku did not hang about for Harry Giese's permission to go back to Mumeka; they took off in their tractor and Land Rover back along the road that had been made six years earlier 'to open up that part of the Arnhem Land Reserve adjacent to and west of the Liverpool River' in an expedition led by the very same Ted Evans, then chief welfare officer.

Back then, Evans outlined some advantages to be derived from the road link:

The first immediate advantage from this road link will enable the Superintendent of Maningrida to have ready and easy access to those areas to the south where native peoples for varying reasons still choose to live away from settled areas ...

A second important advantage ... is the opening up of good pastoral country to the west of the Liverpool River. The presence of cattle and buffaloes in excellent condition ... would seem to confirm that these pastoral areas have considerable potential and should be developed. (Evans 1963: 12)

Indeed, somewhat ambitiously, Evans (1963: 12-3) notes:

Out of this I see emerging a plan for Maningrida whereby its forestry, agricultural and small livestock projects will be developed on the eastern side of the Liverpool River and its cattle and buffalo development will be undertaken on the western side.

These earlier observations and the subsequent use of the road for reoccupation are poignant on two grounds.

First, the Kuninjku found an unexpected ally in the form of the quietly spoken but formidable superintendent John Hunter (Gillespie 1982). ${ }^{7}$ Hunter set up a bank account for the Kuninjku and facilitated savings by them via a voluntary 'chuck in' of saved cash, mainly from art sales, which allowed them to purchase vehicles. Hunter also used the road himself (he loved driving, often at night) from the earliest days of decentralisation to maintain a communications and supply line to Mumeka (and other embryonic outstations) on a fortnightly basis. Perhaps more aware than anyone of the destructive impact of settlement life on Kuninjku - as its long-serving superintendent, he was there when they centralised in 1963- he became the champion of decentralisation.

7 Gillespie relates how in 1974 Hunter was moved from Maningrida when he stood down a number of white DAA staff there because he perceived that Aboriginal people were being smothered, and how subsequently members of the Maningrida Council occupied the DAA offices in Darwin and demanded his return — a demand the DAA acceded to (Gillespie 1982: 6). 
Hunter meticulously kept annual Aboriginal contact tables, one of a number of governmental record-keeping tools that the state forged to ensure legibility (Scott 1998), as required by the Welfare Branch. And so he provides a record of the precise time of Mumeka's administrative birth; in 1969-70, Hunter (1970: 72) enumerated ' 11 people at Mormaka'.

Second, Evans' developmental optimism took a very different direction. Such optimism had begun in 1884, when explorer and surveyor David Lindsay (1884) had promising things to say about the pastoral potential of some of the savannah grasslands in the region of the Liverpool River - an assessment repeated in almost all patrol officer reports; it was hard to quell. Evans (1963: 19) even thought that the imminent exploitation of bauxite deposits on Gove Peninsula would create a future important market for locally produced beef and other foodstuffs.

The development that did occur was very different from that anticipated in 1963. Hunter's (1974) handwritten documentation provides early information on this new form of local economy: he notes that the 51 Gunwinggu at Mormega community are 'very active hunters and gatherers' and that 'they are also one of the better sources of craft work for Maningrida Arts and Crafts that fully supports their work'. He notes that they have erected traditional housing at Mormega (dry season) and Manbulugadi (wet season). Elsewhere, Hunter notes:

This group is evidently determined to stick it out at Mormega this year. I have been visiting the place each fortnight over the dry season and I am impressed by their determination and production capacity when they decided that they need a vehicle to stay on in the wet. They cut 8 miles $[13 \mathrm{~km}]$ of track through eucalypt forest in just over 6 days, no mean feat, in order to demonstrate that there is an alternative to moving out during the wet. The M.P.A. [Maningrida Progress Association $]^{8}$ has since agreed to carry their supplies each fortnight to the landing. (Hunter 1973: 2-3)

In 1963, Evans (1963: 10) observed that '[h]istory has shown that throughout Australia road access and links with other settled areas has been a necessary prerequisite for the opening up of undeveloped areas'. Not only did the existing track between Maningrida and Mumeka open up the means to export art and craft and import Western supplies, but it also opened up new hunting grounds. Kuninjku clearly saw the value of such bush roads for external communications when they made their own to Manbulgardi.

8 The Maningrida Progress Association is a community-owned retail operation established in 1968 that delivered supplies via a 'tucker run' to outstations from the early 1970s until 1999, when the operation was purchased by the Bawinanga Aboriginal Corporation. 


\section{Mumeka and the new policy environment}

From 1972 and the election of the Whitlam Government, three important things happened: first, the emphasis on managed assimilation and colonial domination in remote regions was relaxed and there was talk of self-determination; second, there was a commitment to land rights and so greater authority was vested with Traditional Owners; and third, the Federal Department of Aboriginal Affairs (DAA) was established. This in turn opened up possibilities for greater support for outstations, policy advocacy on their behalf and much policy angst in Canberra about the future of outstations, with reference often focused on outstations as places of residential fixity.

Hunter implemented the new policy quickly, moving to operate as an enabling community adviser. And in 1974, in that role, he assisted people at Mumeka with an application for a now formalised and properly bureaucratised establishment grant, with a ceiling of $\$ 10,000$ (Hunter 1974).

The grant was quickly approved. In correspondence, it was emphasised by the department that the funds approved and assets purchased should be used only for the purposes for which they were provided; there was a requirement for quarterly financial statements, audited annual statements and auditor's reports, together with a certificate that funds had been used for the purposes stipulated. On 23 October 1974, Anchor Gulumba, leader, put his mark, ' $\mathrm{X}$ ', to the acceptance form, acknowledging that 'I accept the funds approved in the above letter on the terms and conditions stated therein'.

This exchange is instructive on a number of counts. To get assistance - in this case, a boat and some rudimentary building material and hand tools-groups needed to show commitment. And there was a hint in Hunter's application that support would enhance engagement with commerce via a fishing venture. The application was for a group living between two places, Mormega and Manbulugadi; and while Mumeka was unincorporated, a Mormega Society Account was established to receive the cash. Bureaucratic entanglements and legal obligations for the illiterate Gulunba came with self-determination and government support.

Direct links between the Commonwealth and places like Mumeka and people like Gulunba, who did not speak English, were clearly not sustainable. Benign John Hunters would not be there forever; something had to change.

In June 1975, H. C. ('Nugget') Coombs made one of his visits to Maningrida and travelled to Mangallod outstation (near Mumeka) as a member of the Council for Aboriginal Affairs. The council had its own concerns about the survival prospects of outstations; the most basic long-term threat to their future was 
identified as environmental, with a concern that a combination of sedentarism, new technology and population growth would deplete resources (see below). Other important observations included a view that if decentralisation was to meet the psychological needs of participants, it needed to remain an Aboriginal initiative (Council for Aboriginal Affairs 1976).

An important paper from 1974 was 'Decentralization trends in Arnhem Land' by Bill Gray (1977). Gray was a DAA official, who coincidentally accompanied Evans in 1963 in the patrol to establish a road link between Oenpelli and Maningrida. Like others at the time, Gray noted the need at outstations for communications and services, highlighting that groups did not want resident non-Aboriginal people in their communities and so the need for flexible service delivery models (Gray 1977: 114-23). ${ }^{9}$

Pondering the future of decentralisation and whether it was a passing phase, Gray predicted:

[W] hether it is or not will depend in large measure on the attitude taken by those who administer and determine government policy and its translation into action. If services and resources (financial and otherwise) are restricted to established settlements and mission stations, then no doubt decentralization will have a limited future. On the other hand, if our organization (i.e. the Department of Aboriginal Affairs) is designed to be responsive to the needs of Aborigines, as determined by them, then we will be committed to assisting these groups in their endeavours to re-establish themselves in their own traditional countries ... Finally, I should underline that I believe decentralization constitutes one of the most positive steps taken by 'tribal' Aborigines to regain their independence and, most importantly, to re-establish their relationship with the land. (Gray 1977: 120)

Andy Hazel, community adviser for a short time at Maningrida in 1974, provides a somewhat different perspective. Much of his report (Hazel 1974) is focused on the continuing involvement of non-Aboriginal staff at Maningrida and the issue of dependency, but his report is also one of the few that mentions selfdetermination and the interdependence between Maningrida and outstations. Hazel suggests that while Aboriginal people resent the presence of too many Europeans in Maningrida, they are paradoxically highly dependent on them. He observes that people at outstations exhibit a great deal of independence and self-reliance, and notes: 'The out-stations are perhaps the most important feature of Maningrida. I personally feel that the future of Maningrida lies not in developing Maningrida proper but the outstations' (Hazel 1974: 94).

9 The paper was originally presented at the Australian Institute of Aboriginal Studies Symposium on Social and Cultural Change in Canberra in 1974 and was widely circulated and quite influential prior to publication. 
And later: "Self "determination" is most certainly the key note with regard to "outstations" and any interference with the exception of support sought by the people themselves must be discouraged' (Hazel 1974: 97-8).

The most significant upshot of all this policy work was recognition of an urgent need for a formal outstation resource agency based in Maningrida to service outstations.

\section{What happened to Mumeka and the Kuninjku, 1979-2009?}

I lived at Mumeka during 1979 and 1980 and have been back there on more than 50 visits since. It is not easy to summarise what has happened there and why in a short space, but I will try, using the past tense until 2009.

When I lived at Mumeka, and even now when I am there, I used it as a lens through which to look at what I refer to as the Kuninjku 'hybrid or diverse' economy (Altman 2010) - a productive economy that is deeply socially and environmentally embedded. I find it difficult conceptually to differentiate Mumeka-the-place from the people who own the place and the people who inhabit it. In many ways, Mumeka has become more of an infrastructural node and less of a real, or even imagined, community.

The fortunes of Mumeka-the-place have been intricately linked to the role played by the Bawinanga Aboriginal Corporation, incorporated in 1979. I have written about this organisation elsewhere (Altman 2008); it was constituted to assist people at outstations as a charitable resource or service organisation. It superseded the Maningrida Outstation Resource Centre, which disappeared in 1977 when Minister for Aboriginal Affairs Ian Viner illegally revoked the permits of three of its white staff, Dan Gillespie, Peter Cooke and David Bond, protégés of the Hunter approach, for being too progressive, but that is another story (see MacCallum 1978).

Over the 30 years to 2009, Bawinanga grew as an organisation to become the second-largest incorporated by the Registrar of Indigenous Corporations. Its spectacular growth began in the 1990s, when it became the largest and most financially successful Community Development Employment Projects (CDEP) organisation in remote Australia. Bawinanga was an institution born of the selfdetermination era that advocated for its members and delivered on multiple objectives: it was the provider of key services, mainly housing and community facilities, roads and regular supplies; it ran employment and training programs; and it successfully established a range of community and commercial enterprises 
over many years, the most significant of which have been Maningrida Arts and Culture and the Djelk Community Rangers. Bawinanga has always been Maningrida-based, and as it has expanded as a development agency, many of the opportunities it has provided have been in the township. And while Bawinanga has advocated vigorously for health, educational and social security services on behalf of its members, it has never been responsible for their delivery.

Bawinanga's activities have transformed Mumeka in a physical sense as a place, as evident in the aerial photograph from GoogleMaps (Figure 14.2): two threebedroom houses, two earlier tin houses on concrete slabs, a school and preschool, a women's centre and teacher accommodation, as well as reticulated water and ablution facilities, and a fine gravel airstrip. Mumeka is a far more solid infrastructure node than it was in 1972 when people lived there in bark shelters and on sleeping platforms, or in 1979 when people lived in corrugated-iron sheds with dirt floors and nothing else.

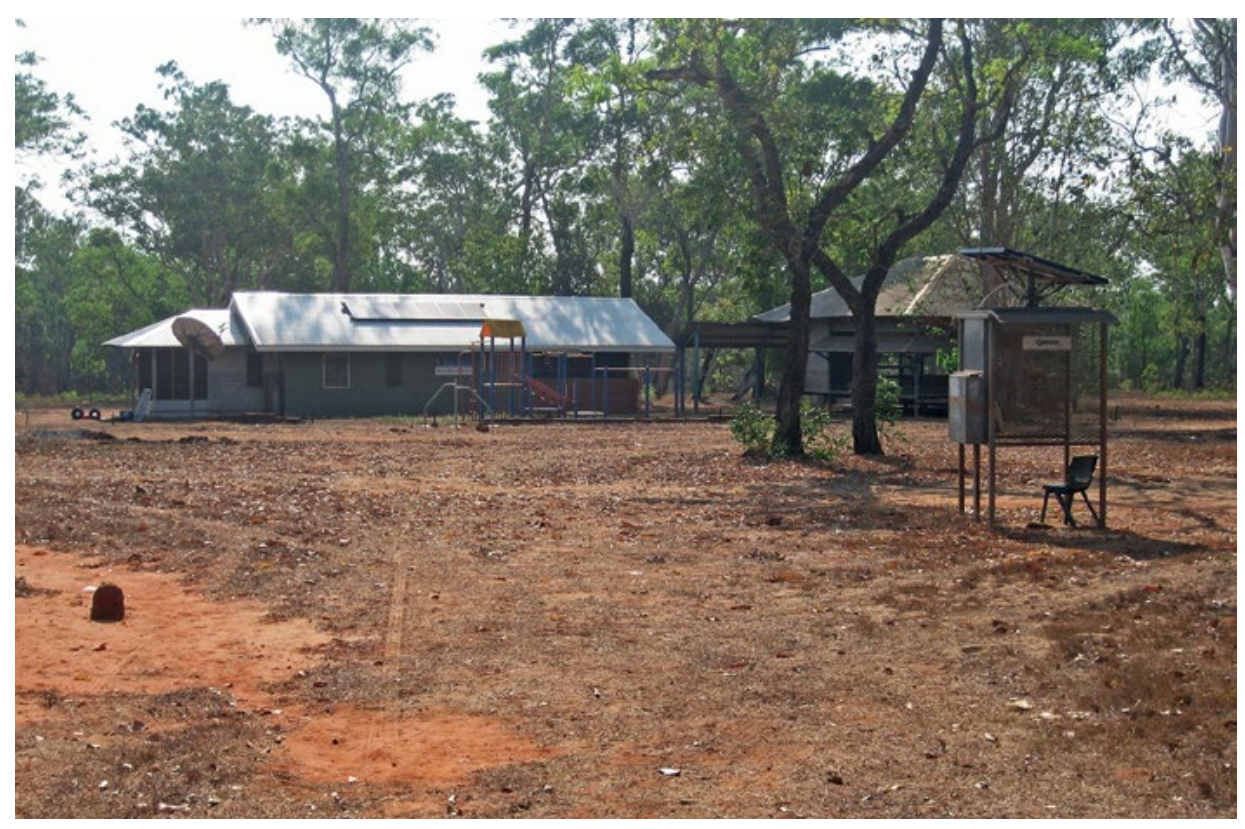

Figure 14.2 Mumeka house and school.

Photo: Jon Altman 


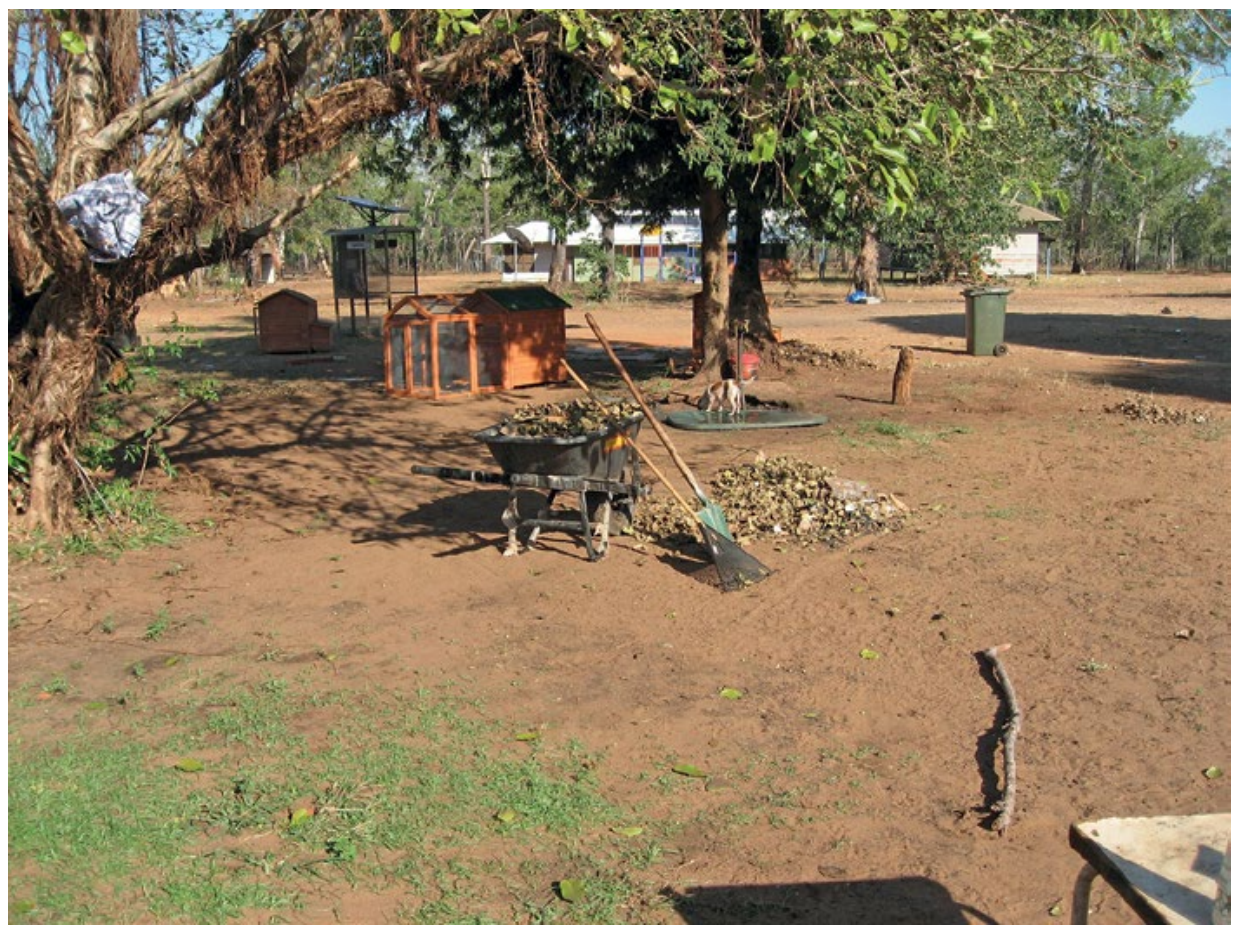

Figure 14.3 'Development' comes to Mumeka, July 2012.

Photo: Jon Altman

Through its responsiveness, Bawinanga has also assisted Kuninjku with the development of a number of other smaller infrastructural nodes, as the group associated with Mumeka has splintered for reasons of family politics and new outstations have been established, each connected by formed tracks. The improvement in the road between Maningrida and Mumeka has also facilitated travel, even by two-wheel-drive sedan, between the two places for longer periods in the annual seasonal cycle than in the past.

Bawinanga also assisted Kuninjku people with livelihood; it has helped people save for, purchase and maintain vehicles; it has helped people with the tricky business of getting a gun licence and firearms; and, most importantly, it has purchased, marketed and promoted Kuninjku art to such an extent that by 2008-09, I estimate that more than \$1 million per annum was returned just to Kuninjku artists. And art was the only significant commodity export from this region.

Paradoxically perhaps, the enduring characteristics of Kuninjku-hunting skills and adherence to tradition including art and craft production and high ceremonial participation - that saw them marginalised in Maningrida in the 1960s now gave them very different heightened regional status as people who 
could control their own destiny. And so Maningrida became a more welcoming place for Kuninjku, and for more and more it became their principal, if not permanent, place of residence. Through their arts expertise, Kuninjku came to dominate some Maningrida-based institutions like the Babbarra Women's Centre, where they worked (and still do) as highly creative screen-print artists.

The improved roads, greater access to vehicles and discretionary cash from art sales made the Kuninjku more and more mobile; people increasingly drove from Mumeka to Maningrida for day shopping trips and from Maningrida to Mumeka for day or night hunting trips; some people even commuted for work. This high mobility made the delivery of services to Kuninjku either in town or in country extremely difficult, especially if provided on an orthodox basis. One consequence has been that getting medical attention to Kuninjku has been difficult, as alluded to by Evans in his 1969 report. Kuninjku are a high death-rate, high birthrate community. Another hurdle is that getting standard Western education to Kuninjku, whether in Maningrida or at Mumeka, is extremely challenging. And, so, as in 1969, while Kuninjku school attendance is minimal and functional English literacy among Kuninjku is almost absent, the maintenance of a full array of Kuninjku clan-lects and other fine-grained linguistic expressions of identity, as described in the work of Murray Garde (2013), which is extremely rare in Australia today, continues strongly. And while a few Kuninjku do hold regular jobs, they are notorious for absenteeism, irregularity of work hours and employment mobility owing to competing priorities.

\section{The great crash}

Until 2009, one interpretation of what happened to the Kuninjku might suggest that they have engaged with capitalism and the state on their own terms with some success. Another interpretation is that the Kuninjku way of living is socially dysfunctional and an abject failure. This latter view came to dominate popular and policy discourse even as some Kuninjku like Mawurndjul were meeting Jacques Chirac in Paris in 2006 and being hailed as cultural diplomats. Bawinanga, an institution born of the self-determination era, valiantly tried to shore up the defences against the latter demeaning interpretation, but the national tide of policy history, aided and abetted by some black and white public intellectuals such as Noel Pearson (2009) and Peter Sutton (2009), seems to have won the day: there is now a dominant public perception that the government project to 'close the gap' in Indigenous disadvantage is not possible at outstations and that the maintenance of fundamentally different cultural norms by groups like the Kuninjku is primarily responsible for their slow or 
unsuccessful integration into the mainstream. The GFC of 2008-09 also played a part, as Kuninjku engagement with capitalism via their creation of fine art declined rapidly as market demand eroded.

In chronological order, the following events rocked the established Kuninjku and Bawinanga order: in 2004, the abolition of the Aboriginal and Torres Strait Islander Commission (ATSIC), an institution (like Bawinanga) with certain defined functions, which was blamed for all ills in Indigenous affairs; from 2005, the reform of the CDEP and the demeaning of outstations as 'cultural museums' by the then Minister for Indigenous Affairs, Amanda Vanstone; in 2007, the NT Intervention, which Bawinanga strongly opposed ${ }^{10}$ and Kuninjku largely avoided by retreating back to outstations; in 2008-09, the GFC; and, perhaps of greatest significance, also in 2009, the departure of CEO Ian Munro, who had worked at Bawinanga for 18 years. The last marked the end of the committed manager from the self-determination days; suddenly it was the era of fly-in-flyout (FIFO) management and a new breed with limited local experience and little business acumen.

Looking to curry favour with the new neoliberal approach in Canberra, the newly recruited management at Bawinanga promoted 'fake capitalism' (Wiegratz 2010) not seen in the region since the 1960s. And the new approach failed so spectacularly that in just two years, Bawinanga went from surplus to being insolvent with a $\$ 10$ million debt. In the name of development, a moral space has emerged for vulture capitalism (Lowenstein 2013) and incompetence.

This new approach of imagined development was visible in July 2012, when on a visit to Mumeka, I saw the construction of wooden chicken coops (imported as kits from Denmark), market gardens with trickle irrigation and pizza ovens - all delivered with copious Canberra money from a program called the Community Action Plan. In October 2012, Bawinanga went into special administration, where it remains at the time of writing (May 2014): ${ }^{11}$ the chicken coops were wrecked before they hosted a chicken, the market gardens are now in disrepair, and the pizza oven has never been used to my knowledge (it looks splendid in the middle of Mumeka, not far from a white cross, as a symbol of some as yet to be fathomed cargo).

\footnotetext{
10 Including underwriting the unsuccessful High Court case Wurridjal $v$ Commonwealth in 2008 that challenged the constitutional validity of the compulsory acquisition of Aboriginal townships for five years under the NT Intervention.

11 Bawinanga came out of special administration on 1 July 2014, having most of its public liabilities forgiven and its private liabilities covered by a loan from the Maningrida Progress Association. As this volume goes to press, it remains on relatively shaky financial footings compared with the pre-2009 period.
} 


\section{The Kuninjku enigma}

Not long ago, in 2006, I suggested a little prematurely that at the start of the twenty-first century through their art and by maintaining other aspects of their local economies like hunting, Kuninjku living at or associated with outstations have succeeded in realising a hybrid form of economy that is thoroughly geared to their own emergent aspirations. But I also noted that this is not enough, because while they might be doing what the state wants, they are not doing so in accord with the broader Australian imaginary of how success should be constituted. I also suggested that the strategic use of art as a source of political and economic power has allowed people associated with Mumeka to define their identity and differences, mark social and geographic boundaries, and find an economic means to live on country when they so wish (Altman 2006, 2010).

Arguably, what had been defined as 'the Gunwinggu problem' in the 1960s emerged by the early twenty-first century as 'the Kuninjku enigma'. It was precisely because Kuninjku were 'like animals eating bush tucker' and because of their 'innate pride in traditional skills', as Evans put it in 1969, that Kuninjku were able to construct a hybrid form of domestic economy that at once engaged successfully with capitalism and provided sustenance.

This way of living was risky because it became increasingly predicated on an ever-expanding arts market and mediation provided by a politically robust and commercially successful Bawinanga Aboriginal Corporation managed by skilled outsiders empathetic to Kuninjku aspirations; and it needed state support that facilitated relative autonomy and local self-determination. In a very short time, all the conditions for relative Kuninjku success evaporated and now many are more impoverished and dependent than ever. Aspects of their hunting economy have declined owing to loss of many edible species, particularly from the invasion of the cane toad, but also other feral pests like buffalo, pig and cats, and exotic weeds. The Council for Aboriginal Affairs' (1976) environmental concerns of endogenous degradation have proven unfounded, while the Australian state and its agents have never considered compensation for loss of livelihood owing to such resource depletion and declining food security. In similar vein, as the arts economy has crashed-Kuninjku in 2013 received just 15 per cent of what they received in 2008-09-there has been no thought given to restructuring bailout packages of $\$ 100$ million, as occurs for already heavily subsidised Holden car workers or employees of the nearby Gove alumina refinery, which was mothballed in early 2014.

There is no doubt that until recently the livelihood that Kuninjku eked out for themselves met their aspirations; but what of the bureaucratic imagination? Back in the 1970s there was considerable angst about ensuring that outstations 
received adequate access to health and education services, but that angst was never converted into effective state action in terms of either the level of investment or a search for innovative delivery options. Indeed, as Kuninjku became more and more mobile, the prospects for delivering education and health services declined even before the effective, flexible models that might have been envisioned by Gray (1977) had been tested on a longer-term basis.

There were in fact a few experiments along the lines suggested by Ted Evans in 1969, but for short periods, and finding teachers with the motivation and physical attributes' to be both a teacher and a pupil proved difficult, although there have been some rare outstanding examples among Kuninjku, like Murray Garde. Bill Gray's (1977) concerns proved at one level unfounded: resources were largely limited to townships, yet outstations continued. But his observation that services needed to be responsive to needs as determined by the people, as the rhetoric of self-determination implied, never eventuated. And because such services were not a high priority for Kuninjku, who were happy to trade-off a less-serviced life for the sake of autonomy on country, this left a convenient space that resulted in education and health services being a conveniently low priority for all parties. As for the prediction by Andy Hazel (1974), among others, that the future of the Maningrida region lay in outstations, not the township, this does not seem to be the case at present, with the demographic pendulum swinging back heavily in favour of Maningrida, at least according to the most recent five-yearly census.

Where does all this leave Mumeka and Kuninjku? Some remain committed to the outstation and the way of life there, preferring it to the prospects of living in what is called 'new sub' or Palmerston, the new bland housing estate in Maningrida, eking out a living on welfare and much-diminished art sales and driving out at night to shoot and bone out feral buffalo or pigs to supplement meagre township diets. Others choose town living over country. What is undeniable is that after decades of engaging successfully with capitalism through their mediated arts practice of high domestic and global reputation, having fired their best entrepreneurial and individualistic shots, Kuninjku are again impoverished, as they were in the 1960s, and highly dependant on the state. Almost all lack Western education and norms - the supposed elixir for mainstream economic integration imagined by politicians, bureaucrats and others. And Kuninjku are unprepared for and uninterested in any precarious FIFO work that might be available in industries like mining or tourism on other people's country in Gove or Kakadu National Park.

One would not want to prematurely write off the enigmatic Kuninjku, exposed in 2013 as they were in 1963, or their outstations. In the 1960s, they combined hunting and artistic skills as a lifeline to reassert their identity, rights in land and relative autonomy; and for a time this strategy, promoted by many, including 
me, worked, at least in regional terms. What will now emerge as the imagined hope and future for the children of John Mawurndjul, many already fine artists, and his grandchildren remains unclear. It should not, I think, just be a choice between the risk of being an artist and the mundaneness of being a tyre fixer at the Ye Ya workshop. In today's precarious late-capitalist world, there have to be other less risky alternatives to living at Mumeka, or in Maningrida, or most likely living between both.

\section{References}

Altman J. C. 1987. Hunter-Gatherers Today: An Aboriginal Economy in North Australia. Canberra: Australian Institute of Aboriginal Studies.

Altman, J. C. 2006. The invention of Kurulk art. In J. C. Altman (ed.), Mumeka to Milmilngkan: Innovation in Kurulk Art. Canberra: Drill Hall Gallery, The Australian National University, pp. 17-33.

Altman, J. C. 2008. Different governance for difference: The Bawinanga Aboriginal Corporation. In J. Hunt, D. Smith, S. Garling and W. Sanders (eds), Contested Governance: Culture, Power and Institutions in Indigenous Australia. Canberra: ANU E Press, pp. 177-203.

Altman, J. C. 2010. What future for remote Indigenous Australia: Economic hybridity and the neoliberal turn. In J. C. Altman and M. Hinkson (eds), Culture Crisis: Anthropology and Politics in Aboriginal Australia. Sydney: UNSW Press, pp. 259-80.

Council for Aboriginal Affairs 1976. Report on Arnhem Land. Canberra: Australian Government Publishing Service.

Eccles, J. 2010. Queen honours Aboriginal artists. News: Aboriginal Art Directory, 18 June.

Evans, E. C. 1963. Patrol to establish road link between Oenpelli and Maningrida. In Proposed road between Oenpelli and Maningrida, NAA 1966/3790, folios 10-19. National Archives of Australia, Darwin.

Evans, E. C. 1969. Maningrida. In Social and cultural change-Maningrida, NAA 1973/5087, folios 11-35. National Archives of Australia, Darwin.

Evans, N. 2003. Bininj Gun-wok: A Pan-Dialectical Grammar of Mayali, Kuninjku and Kune. 2 vols. Canberra: Pacific Linguistics.

Farmer, P. 2005. Pathologies of Power: Health, Human Rights and the New War on the Poor. Berkeley: University of California Press. 
Garde, M. 2013. Culture, Interaction and Person Reference in an Australian Language. Amsterdam: John Benjamin.

Gillespie, D. 1982. John Hunter and Maningrida-A chorus of alarm bells. In P. Loveday (ed.), Service Delivery to Outstations. Darwin: North Australia Research Unit, pp. 1-7.

Gray, W. J. 1977. Decentralization trends in Arnhem Land. In R. M. Berndt (ed.), Aborigines and Change: Australia in the '70s. Canberra: Australian Institute of Aboriginal Studies, pp. 114-23.

Hazel, A. 1974. Community adviser report-Maningrida, 27-5-74. In Maningrida-Continuing involvement of non Aboriginal staff, NAA 1974/700, folios 89-98. National Archives of Australia, Darwin.

Hunter, J. 1970. Aboriginal population contact table, Maningrida settlement, 1969/70 dated 27.8.70. In Population movement and statistics Maningrida settlement, NAA 1976/844, folio 72. National Archives of Australia, Darwin.

Hunter, J. 1973. Request for loan money, Mormega community. In Movement of Gunwinggu People to Mormega, NAA 1973/8239, folio 2-3. National Archives of Australia, Darwin.

Hunter, J. 1974. Report on application for funds detailed considerations dated 16/9/74. In Re-location of Mormega Group-Maningrida, NAA 1974/1466, folios 1-2 (double-sided). National Archives of Australia, Darwin.

Kaufmann, C. (ed.) 2005. <<rarrk>> John Mawurndjul: Journey through Time in Northern Australia. Basel: Schwabe Verlag.

Kettle, E. 1967. Gone Bush. Sydney: F. P. Leonard.

Lindsay, D. 1884. Mr. D. Lindsay's explorations through Arnheim Land. South Australian Parliamentary Paper No. 239, 1883-84. Adelaide: Government Printer.

Lowenstein, A. 2013. Profits of Doom: How Vulture Capitalism is Swallowing the World. Melbourne: Melbourne University Press.

MacCallum, M. 1978. Viner muscles in on Maningrida. Nation Review, 27 April - 3 May.

Pearson, N. 2009. Up from the Mission: Selected Writings. Melbourne: Black Inc.

Scott, J. C. 1998. Seeing Like A State: How Certain Schemes to Improve the Human Condition Have Failed. New Haven, Conn.: Yale University Press. 
Sutton, P. 2009. The Politics of Suffering: Indigenous Australia and the End of the Liberal Consensus. Melbourne: Melbourne University Press.

Volkenandt, C. and Kaufmann, C. (eds) 2009. Between Indigenous Australia and Europe: John Mawurndjul. Berlin: Reimer.

Wiegratz, J. 2010. Fake capitalism? The dynamics of neoliberal moral restructuring and pseudo-development: The case of Uganda. Review of African Political Economy 37(124): 123-37. 
This text is taken from Experiments in self-determination: Histories of the outstation movement in Australia, edited by Nicolas Peterson and Fred Myers, published 2016 by ANU Press, The Australian National University, Canberra, Australia. 